\title{
unindra
}

Universitas Indraprasta PGRI

Address: Jl. Nangka No. 58 C (TB. Simatupang), Kel. Tanjung Barat, Kec. Jagakarsa, Jakarta Selatan 12530, Indonesia.

+62 21 7818718-78835283; url: www.unindra.ac.id; cultural.syndrome@unindra.ac.id

\section{Islamic Memes as Media of Da'wah for Millenials \\ Generations: Analysis of Visual Language On \\ Islamic Memes With Illustration Style}

Winny Gunarti Widya Wardani *1,

Ahmad Faiz Muntazori ${ }^{2}$

Departement of Visual Communication Design,

Universitas Indraprasta PGRI ${ }^{12}$

Correspondence regarding this article should be addressed to:

Winny Gunarti Widya Wardani, winny.gunartiww@unindra.ac.id,

\section{Article History}

Received : 31-05-2019

Revised : 01-06-2019

Accepted : 25-06-2019

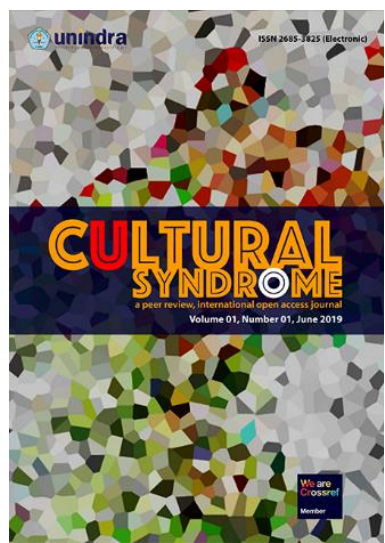

Cultural Syndrome

a peer review, internasional open access journal e-ISSN: 2685-3825

Editor: (D)Ahmad Faiz Muntazori

Publication details, including author guidlines https://journal.unindra.ac.id/index.php/cusy/ about/submissions\#authorGuidelines

\section{How to cite this article (MLA 8th)}

Wardani, Winny Gunarti Widya, and Ahmad Faiz Muntazori. "Islamic Memes as Media of Da'wah for Millennials Generations: Analysis of Visual Language On Islamic Memes With Illustration Style." Cultural Syndrome, Vol.1, No.1, 2019, pp. 61-78., doi.org/10.30998/cs.v1i1.16

\section{The readers can link to article via https://doi.org/10.30998/cs.v1i1.16}

SCROLL DOWN TO READ THIS ARTICLE

Universitas Indraprasta PGRI (as Publisher) makes every effort to ensure the accuracy of all the information (the "Content") contained in the publications. However, we make no representations or warranties whatsoever as to the accuracy, completeness, or suitability for any purpose of the Content. Any opinions and views expressed in this publication are the opinions and views of the authors, and are not the views of or endorsed by Universitas Indraprasta PGRI. The accuracy of the Content should not be relied upon and should be independently verified with primary sources of information.

\section{(c) (1) (8)}

This work is licensed under a Creative Commons Attribution-NonCommercial 4.0 International License.

Copyright by Winny Gunarti Widya Wardani, Ahmad Faiz Muntazori (2019)

The authors whose names are listed in this manuscript declared that they have NO affiliations with or involvement in any organization or entity with any financial interest (such as honoraria; educational grants; participation in speakers' bureaus; membership, employment, consultancies, stock ownership, or other equity interest; and expert testimony or patent-licensing arrangements), or non-financial interest (such as personal or professional relationships, affiliations, knowledge or beliefs) in the subject matter or materials discussed in this manuscript. This statement is signed by all the authors to indicate agreement that the all information in this article is true and correct 


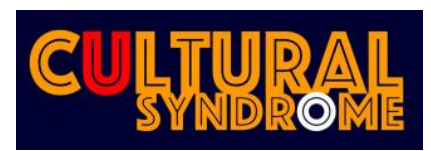

Vol.1, No.1, 2019, pp. 61-78

e-ISSN: 2685-3825

https://doi.org/10.30998/cs.v1i1.16

\title{
Islamic Memes as Media of Da'wah for Millenials Generations: Analysis of Visual Language On Islamic Memes With Illustration Style
}

\author{
Winny Gunarti Widya Wardani ${ }^{1}$, Ahmad Faiz Muntazori ${ }^{2}$ \\ Visual Communication Design, Faculty of Language and Art, \\ Universitas Indraprasta PGRI, Jakarta, Indonesia ${ }^{12}$
}

\begin{abstract}
Islam as a religion of da'wah has obliged every Muslim to play a role in spreading the truth of the Qur'an. In the era of information technology like today, the spread of Islamic teachings can be done in various ways, including through memes. For millennials who are proficient with technology, Islamic memes are an alternative media for da'wah. This is due to the power of memes in conveying messages through image visualization and humor-style text. Islamic memes are generally distributed via the internet and messaging applications on smartphones. Most Islamic memes are designed using illustration styles. To understand the visual language of memes, this study formulates the question: how to read visual signs in Islamic memes as da'wah media, because the types of da'wah in memes are not only in the form of written text, but also in the form of images? This study uses a combination method, which combines quantitative and qualitative approaches. Quantitatively, this study collects data about the views of the millennial generation on the attractiveness of illustration-style Islamic memes. Whereas qualitatively, an analysis of samples of illustration-style Islamic memes uses semiotic theory to see the structure of design elements as the visual language of da'wah messages. The results of this study are expected to be a reference for the scientific field of visual communication design, as well as encourage the creation of more productive and communicative Islamic memes as da'wah media for millennial generations.
\end{abstract}

Keywords: Islamic memes, media, da'wah, millenial generations, visual language.

Correspondence author: Winny Gunarti Widya Wardani, winny.gunartiww@unindra.ac.id, Jakarta, Indonesia. 


\section{Introduction}

As a religion of da'wah, Islam aims to teach goodness and truth. Every Muslim must do da'wah, as Allah Swt has called in Surah Ali 'Imran verse 104 (QS 3:104): "And let there be [arising] from you a nation inviting to [all that is] good, enjoining what is right and forbidding what is wrong, and those will be the successful".

To understand the meaning of da'wah al-ma'ruf al-munkar, M. Natsir, a figure of Masyumi, the leader of the Largest Islamic Party in Indonesia in the period 1949-1958, interpreting da'wah is not merely conveying, but requires several conditions, namely finding suitable material, knowing the subject's condition preaching appropriately, choosing a representative method, using wise language, also fostering or containing hospitality to disseminate the da'wah so that it can reach and be useful for the community and get the results as expected (Luth 67).

The message of truth in Islam is the essence of da'wah which aims to achieve the highest truth. An achievement to become a human who has faith, and then surrender to the will of Allah (Islam) fully. In this case, da'wah is more oriented to the birth and formation of a holy human life attitude. Religion should be a continuation of the attitude of this holy human life, and come to strengthen it. Truth can not be forced because it will only become a matter of religiousness (Ismail and Hotman 14).

Whereas 'Abd al-Karim Zaidan, in his book Ushul Da'wah (1978) in Ismail and Hotman requires four main elements in da'wah, namely Islam, da'i, mad' $u$, and media (al-wasa'il). The Islamic element, da'I, and mad'u, is described by Ismail and Hotman as follows: The Islamic element means da'wah is an invitation to Islam. Islam must be submitted to humanity, in the sense that Islam is a living system that must be realized and enforced on earth, so that da'wah is identical with Islam. The da'I element is the subject and driver of da'wah that determines the success of da'wah. In it there are pillars of da'I, ethics or morals da'I, covering the competencies that need to be possessed. Paradigm da'wah refers to concepts, perspectives, mindsets, assumptions or glasses that must be used by da'I in carrying out da'wah. Next is the element of mad'u or the object of da'wah. Mad'u is a human. In the context of philosophy da'wah, the study of mad'u needs to be seen in its position as a human being, both as individuals and groups, then its tendency, whether intellectual, moral or emotional, or spiritual.

The media element includes the means to convey the message of da'wah. Written by Farihah that in the time of the Prophet and his companions, media da'wah was very limited, in the form of da'wah qauliyah bi al-lisan, da'wah fi'liyyah bi al-uswah, and using letters (rasail). It was only in a century later that media da'wah developed by presenting narrators (qashash) and written essays (muallafat). In the 14th century Hijriah, the development of media da'wah grew rapidly. Da'wah can be done through newspapers, magazines, short stories, illustrated stories, tapes or CDs, films, radio, television, stickers, paintings, advertisements, shows, poems, songs, music, and other art media that can help preachers carry out their duties.

The development of media of da'wah today is inseparable from the method of disseminating information through visual technology that has a variety of imagination, 
both popular, or even virtual, so that religion is also indirectly built by the multiplicity of imagination, namely diversity that builds possibilities in cyberspace. Therefore Piliang (ii) says religion cannot be separated from creativity, because psychologically, the power of imagination is part of the power of creativity. The power of creativity is able to process intangible imagination into a new reality that has never been imagined. These forms of creativity can be in the form of a variety of visual languages from the media of da'wah.

According to Sarup (264), globalization of information through cyberspace is one form of cultural practice that prioritizes figural sensibility, where everyone can access information and interpret visual texts quickly and easily. The development of information technology in the form of visual cultural artifacts is a form of fulfilling the needs of the community which simultaneously contributes to changing the values of human culture in their lives.

In the context of the delivery of da'wah today, where human civilization has made society highly dependent on visual technology, the media of da'wah can take the form of creative media. The presence of social media and instant messaging applications that are widely used on smartphones by the public has also encouraged the spread of da'wah more massively through visual language. This application makes it easy for users to obtain information, pictures, or videos about Islamic teachings in ways that are more interesting, and disseminated in seconds in bulk. Message delivery also becomes more interactive, and can be two-way communication. Among the various forms of media creativity of da'wah through social media and instant messaging applications, the presence of Islamic Memes as a medium of da'wah is among the most widely distributed. Especially if the da'wah target is specifically for millennial generations who are familiar with social media.

A Meme is a visualization of an image, it can be an imitation of a picture or photo, or a self-made illustration, then added with written text for humorous purposes. Meme is a product of mass culture, because it has the ability to form perceptions simultaneously and in bulk through visual language in the form of images and text. Instant messaging applications on smart phones allow Islamic Memes to be disseminated in an easy and fast way. There are Islamic Memes that use illustrations and text, use photos and text, photos by displaying public figures, or only in text using visual typography. In other words, the reality of the message da'wah can be anesthetized through visual language into simulations and cultural forms as marker structures or styles in visual text.

\section{Methods}

The study of Islamic Memes is important, because Islamic Memes are a medium for da'wah in the present which are also seen as works of art. Piliang says, artwork is a vehicle of meaning, where design elements such as points, lines, colors, textures, and shapes are part of the vehicle's meaning. To understand these meanings, it is necessary 
to read the signs by using the science of Semiotics, as a study of signs, sign structures, codes that govern them, and their use in society. There is a relationship that cannot be separated between signs and society, that is in the form of rules or conventions or codes that apply in them, so that the sign can be understood socially (Sarup 264).

Therefore, in relation to the existence of Islamic Memes as a medium of da'wah, and the potential for visual consumption based on the strength of visual elements to convey messages through visual language, this study formulates the question: how to read visual signs in Islamic Memes as a media of da'wah? This study focuses on Memes that use illustrated images and written texts, as the strength of design elements. Analysis of the strength of design elements refers to visual thinking that brings to three forms of visual imagery, namely the kind that we see, the kind that we imagine, and the kind that we draw as a manual strategy to help provide solutions to problems in human daily activities (McKim 7).

The use of combination methods in this study combines quantitative and qualitative approaches. Quantitatively, this study collects data on the views of design creators as millennial generations of the potential appeal of Islamic Memes. Whereas qualitatively, the analysis of Islamic Memes samples in an illustration style uses Semiotic theory to read the meaning of signs denotatively and connotatively as a visual language. The purpose of the combination method is to supplement data that cannot be obtained qualitatively, especially perceptions of Islamic Memes. Combination methods can complement the need for analysis of visual language in Islamic Memes with their potential appeal as media of da'wah. The results of this study are expected to encourage creativity in the creation of Islamic Memes as media of da'wah for the millennial generation that is communicative and informative, as well as a scientific reference for Visual Communication Design.

\section{Result and Discussion}

\section{Islamic Memes on Social Media}

The term of Meme was first adopted by Richard Dawkins in his book The Selfish Gene in 1976, which was then reviewed by Richard Brodie in 1996 in a book called Virus of the mind, the New Science of the Meme. If Dawkins exemplifies Meme forms as "... tunes, ideas, catch-phrases, clothes fashions, ways of making pots or of building arches", Brodie (9) defines "Memes are the secret code of human behavior". He also explained in the chapter on mind and behavior that "not only the building blocks of culture on a large scale making up countries, languages, and religions - but also on a small scale: Memes are the building blocks of your mind, the programming of your mental 'computer'.

Brodie's thinking shows that there are impacts that can influence thoughts and behavior through Memes, and this cannot be separated from the cultural values of the place where the Memes are produced and disseminated. Therefore, the existence of Memes as a form of visual language can produce an interaction between religious values and cultural values. 
Along with the advancement of information technology, Meme creativity in practice continues to develop. Meme Comic Indonesia is one of the Meme communities in Indonesia that focuses on Meme creative works with a humorous tendency. In Meme Dibaca Mim, Meme ( $\mathrm{mim}$ ) is defined as a communication work that is usually made by young people who are successful in laughing at themselves and the events around them. Meme is packaged in the form of humor or parody that aims to entertain. It can also be in the form of writing, photos or images with short words, personal videos, or anything to convey the ideas of the creator so that messages can be received and disseminated to a wide audience (Adhiwiayanti 1 ).

However, it needs to be distinguished, that the application of Islamic Memes as medium of da'wah that is disseminated through social media does not necessarily apply elements of parody, but still needs to refer to the provisions in da'wah, as outlined by Ismail and Hotman, namely: Da'wah in Islam is not propaganda, whether in intention, method, or purpose. The intention of da'wah must be sincere, sincere because Allah Swt. Da'wah must be free from the elements of subjectivity. Da'wah must not be littered with vested interests. How to do it also cannot justify any means. Da'wah must be delivered honestly, meaning without elements of lies or manipulation. Da'wah must be open, meaning it is conveyed humbly, tawadlu, and is willing to accept input or criticism. Da'wah is also free, meaning without coercion, because it aims to convey the truth rather than impose teachings (Amal).

A number of studies on Islamic Memes on social media have been carried out, including research on the phenomenon of the invitation to get married through Memes as a satire, which is distributed through social media. Researcher Rulli Nasrullah from the Faculty of Da'wah and Communication Sciences, Universitas Islam Negeri (UIN) Syarif Hidayatullah Jakarta, saw a kind of phenomenon, especially in big cities and regions that still held the custom that marriage is not just a religious ritual and state administrative procedure, but involves responsibility and readiness, which then used as an excuse to delay marriage. The phenomenon which later became a kind of satire text on social media in the form of Memes to quip those who were not ready to get married was analyzed using a virtual ethnographic approach to trace cultural artifacts about satire and the values contained in the Meme (Liem 41).

Another research on Islamic Memes on social media has also been carried out by Ryan Alamsyah who took the title Ethnographic Analysis of Virtual Meme Islamic on Instagram Memecomic. Islam. This study discusses the social aspects of the reality of Islamic Memes that exist in cyberspace, seeing the interactions that occur in the virtual community world, including with users, and also followers, and discovering the content of cultural values in communication through the Instagram (Alamsyah i).

As part of the data collection technique, this study also conducted observations on adolescents aged 18-21 years with the status of Visual Communication Design students, at Universitas Indraprasta PGRI who live in Jakarta and are heterogeneous. Observations were aimed at knowing the perceptions of the millennial generation of the appeal of illustrated Memes from the perspective of art creators. Based on the results of the survey using the questionnaire as a data collection tool, quantitative data were 
obtained about students' perceptions of design about the appeal of Islamic Memes. The questionnaire was distributed to major respondents, namely respondents as design students who did have knowledge of Islamic art and Meme creativity, so the sample referred to the provisions of stratified random sampling. The minor respondents, who were not too interested in Memes, were not included as data, to avoid visual perceptions that were not in accordance with the objectives of this study.

The questionnaire filling technique uses a Likert scale which is commonly used to measure the opinions or perceptions of a person or group regarding social phenomena defined as research variables. The measurement uses four gradations of answers, namely: strongly agree, agree, do not know, disagree. From 200 questionnaires distributed to design students, researchers managed to collect data on the percentage of 155 design students as major respondents.

Regarding the appeal of Islamic Memes in the style of illustration, the percentage data is obtained as follows: as many as 48 students (31\%) stated strongly agree, 59 students (38\%) agreed, 2 students (1\%) stated they did not know, and 46 students ( $30 \%)$ ) who stated they did not agree. The following is presented in Figure 1.

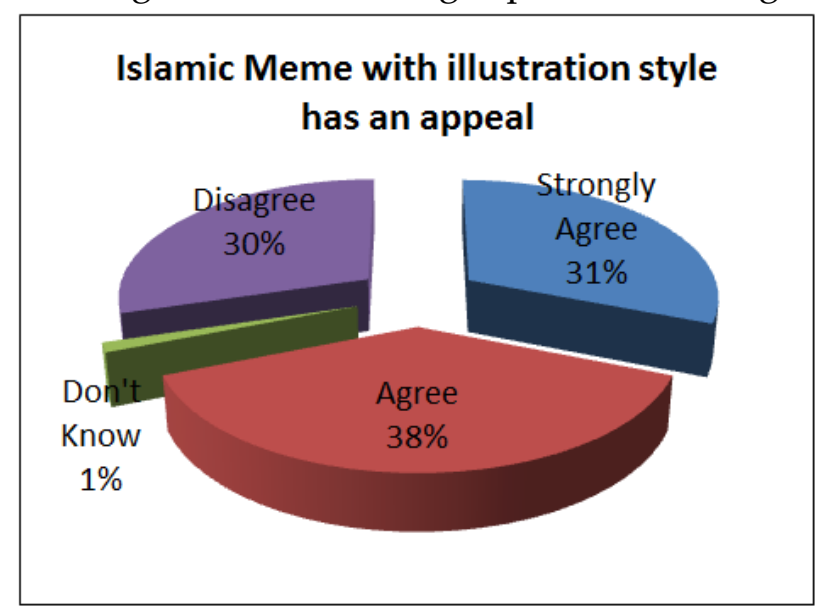

Fig. 1 Percentage of Islamic Memes appeal with Illustration style

In group discussions in class with students who stated they did not agree, further answers were obtained, that illustrations and photographs could have attraction, depending on what was visualized.

Furthermore, the percentage of written text is more important than the illustration image of Islamic Memes showing the following results: 21 students (14\%) stated strongly agree, 45 students (29\%) agreed, 6 students (4\%) stated they did not know, and 83 students $(53 \%)$ who stated they did not agree. The following is presented in Figure 2. 


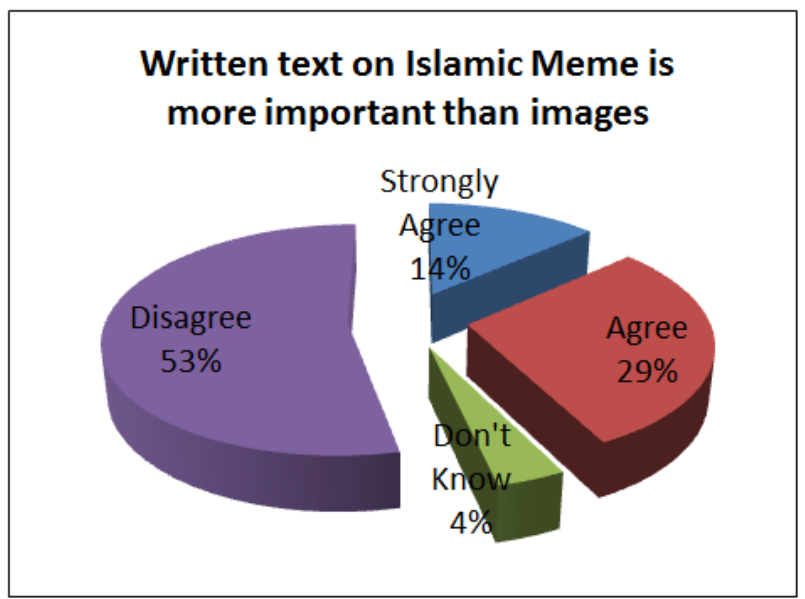

Fig. 2 Percentage of written text on Islamic Memes is more important than images

In class discussions with students who stated they did not agree, further answers were obtained, that the text written on Islamic Memes could function as a supportive design element, not a more important element.

The next percentage reaffirms the function of the text and illustration in Islamic Memes, through the statement that the written text and illustration are equally important. The results of the data show the following: as many as 54 students (35\%) stated strongly agree, 93 students $(60 \%)$ agreed, none $(0 \%)$ stated they did not know, and 8 students (5\%) who did not agree. The following is presented in Figure 3.

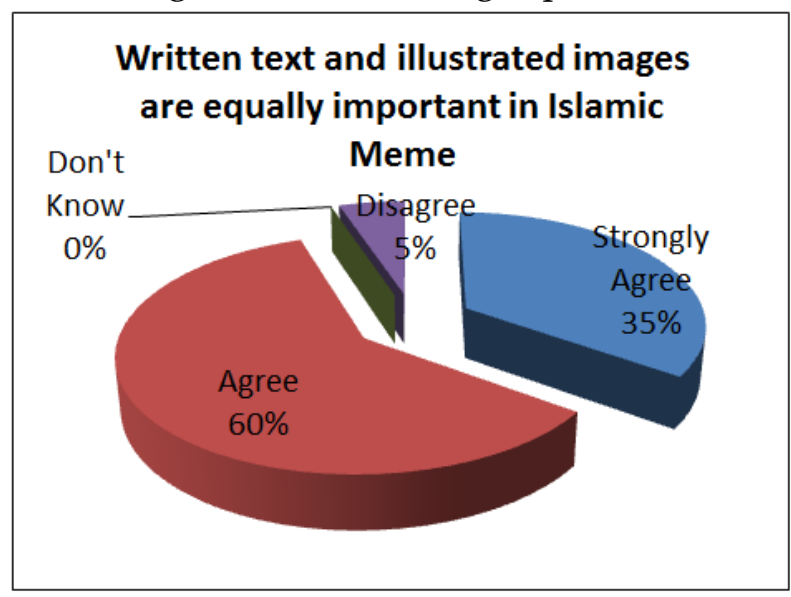

Fig. 3 Percentage of written text and illustrated images are equally important in Islamic Memes

Overall, the results of the above data can be formulated briefly, that Islamic Memes with illustration style as media of da'wah through visual language has the potential to attract. The potential for Islamic Memes with illustration style can be comparable to the potential of Islamic Memes using photographs. But in Islamic Memes with illustration style, it emphasizes originality and creativity in creating images as the visual language of the messenger. In addition, the presence of written text on Islamic Memes can add to this attraction. But the position of written text and illustration images on Islamic Memes 
is equally important. Thus, both illustrated images and written texts, each of which is a design element of an Islamic Memes builder that has the visual strength to attract the attention of the target audience as an effort to convey the message of da'wah. The results of this quantitative data can be used as a reference to more consider the design elements in the process of designing Islamic Memes, as a media for da'wah that have the ability to build perception.

In the context of media technology, Danesi called it that media technology basically resulted in the democratization of art. In contemporary media forms, philosophical, spiritual, and aesthetic themes can be included in creative and innovative ways (Barker).

In other words, Islamic Memes as a form of contemporary media in its design process has the opportunity to translate Islamic teachings into forms of text and image elements that can be more easily understood by society. In a Semiotic significance system, the message of da'wah contained in Islamic Memes can thus be analyzed.

Regarding the formation of perceptions through Islamic Memes, Mustajab (므) has researched the research title Analysis of Surabaya Islamic Youth Reception, About Islamic Memes on Social Media. This study aims to find answers to the acceptance of Islamic Memes among Surabaya youth. The results of the study show: First, most of the informants are in a dominant hegemonic position, when the audience captures and approves the code, symbols, and ideas according to what is the goal. Second, there are stages of the information processing process, namely: sensation, perception, memory, and thinking. Especially when Surabaya Muslim teens receive Memes and spread them again through social media by modifying the Meme's content. Third, there is a view on the content of Islamic Memes, because the teachings of Islam are sacred, so it is inappropriate if something sacred is made as a joke and mixed with political elements on social media.

The large number of Islamic Memes on social media is part of a visual culture that involves visual languages. In the broadest sense, visual culture discusses everything that is visual and plays a role in the formation of mass-like and popular cultural activities. More narrowly, visual culture is shaped by visual technology, including social media. Meme as part of visual culture always involves visual events, Mirzoeff said as a form of fulfilling consumer needs for information, meaning, or pleasure that can be satisfied face-to-face with visual technology (Mirzoeff 5).

\section{Research Highlight}

Based on the above literature data about the provisions of da'wah, then this can be observed through Memes that are widely circulating on social media. The results of observations by researchers, generally Islamic Memes rarely feature parodies in their designs. The style of humor is more presented through its illustrations, especially from the visualization of facial expressions and visual object postures. Most illustrated Islamic Memes feature hijab figures, men dressed in robes or gamis, or feature two hijab figures, and couples in Muslim fashion. The text as a message da'wah generally writes messages taken from hadith or verses in the Al-Qur'an. 
This study took a Meme sample in a random on the Google search engine to be used as a discussion case. The chosen Meme sample is Islamic Memes that display humor in the illustrations and text. The choice of sample with a tendency towards humor is based on the consideration of the limited Islamic Memes style, because generally Islamic Memes emphasize visual and text styles that minimize joke in the message of da'wah. The study selected four Islamic Memes samples, each featuring female illustrations and male illustrations, with different visual styles. Each is also equipped with written text as the main message of da'wah that is to be conveyed.

The Islamic Memes theme in the sample raised an invitation message to enhance and strengthen faith in Allah Swt through daily behavior. The form of faith in Allah includes the application of Tauhid Uluhiyah which means strong belief that Allah 'Azza wa Jalla is the only God who has the right to be worshiped, and lived with all types of worship, both physical and spiritual worship. The meaning of Tauhid Uluhiyah is contained in the word of God in Quran Surah Al Fatiha 5 (QS 1: 5): "It is You we worship and You we ask for help". Or in Quran Surah Hud 123 (QS 11:123) which reads: "And to Allah belong the unseen [aspects] of the heavens and the earth and to Him will be returned the matter, all of it, so worship Him and rely upon Him. And your Lord is not unaware of that which you do". Tauhid Uluhiyah is the beginning and end of religion, the inner and outer part of religion, because there is no god but Allah.

The research underlines the discussion of reading visual signs in Islamic Memes as a medium of preaching. The following are four illustration style Islamic Memes with the Faith in God:

Meme with a da'wah message about the young man who is "sholeh"

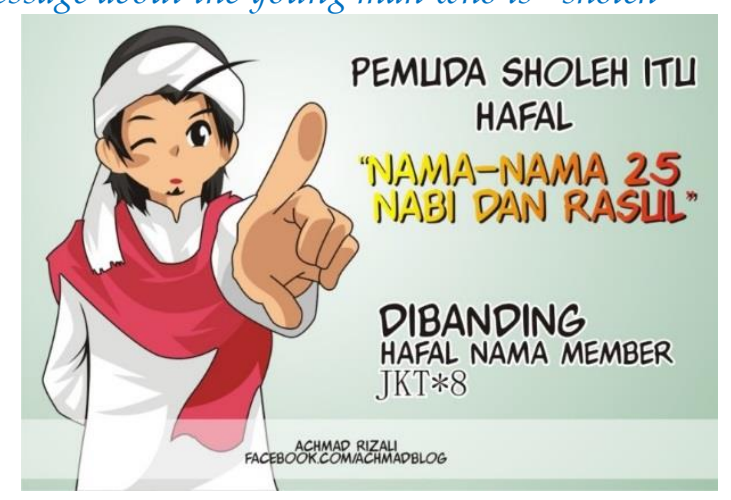

Fig. 4 Islamic Meme about the young man who is "sholeh", Retrieved from http://surgadpbbm.blogspot.com/2018/02/foto-Meme-lucu-islami.html

This Islamic Meme depicts a young man dressed in a robe or gamis, using a head covering in the form of a turban, pointing his index finger forward, blinking one eye. The text on the Meme reads "The 'sholeh' young man can memorize the names of 25 Prophets and Apostles, compared to memorizing the names of JKT members *8". 
Meme with a da'wah message about the role of wife

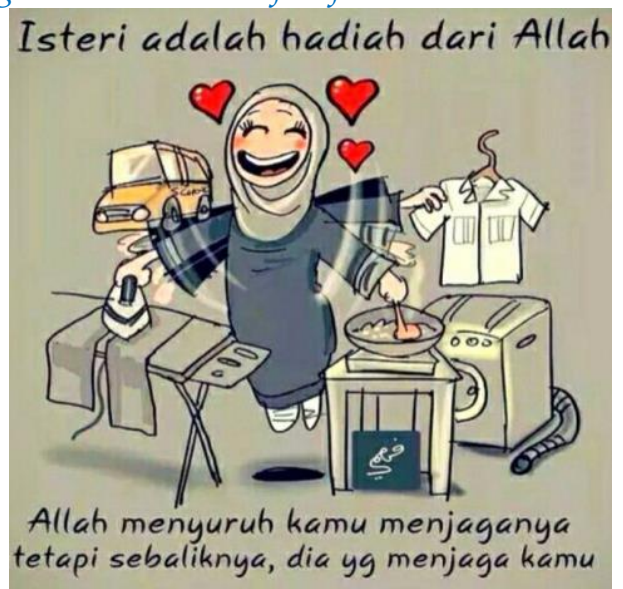

Fig. 5 Islamic Meme about the role of wife, Retrieved from https://newteknoes.com/dp-bbm-dan-Meme-islami-keren-lucu-terbaru/

The Islamic Meme above shows an illustration of a Muslim woman who is working on various household tasks, from washing, ironing, cooking, to taking a child to school, depicted with a laughing expression on her face, and her head decorated with a symbol of "love". The text on the Meme reads "The wife is a gift from God. God tells you to look after her, but on the contrary, she is looking after you."

\section{Meme with a da'wah message to always remember Allah and avoids immorality}

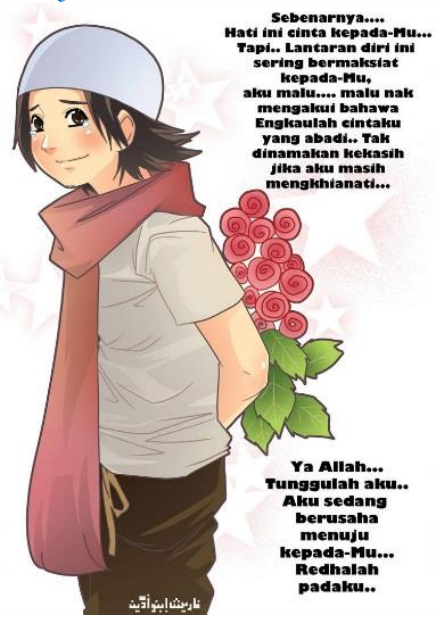

Fig. 6 Islamic Meme invites always to remember Allah and avoids immorality, Retrieved from https://www.deviantart.com/saurukent/art/Love-for-Allah-352503873

The Islamic Meme above shows a Muslim man dressed in fashion, using a headscarf and a scarf. He was seen carrying flowers hidden in the back of his body. The expression on his face did not look smiling, with a glancing eye. The text on the Meme reads, "Actually, this heart is in love with You ... But ... Because this self often accuses You, I'm ashamed ... I am embarrassed to admit that You are my eternal love ... Not 
called a lover if I still betrayed. Oh God ... Wait for me ... I'm trying to get to You ... Be sorry to me ... ".

Meme with a da'wah message to "hijrah"

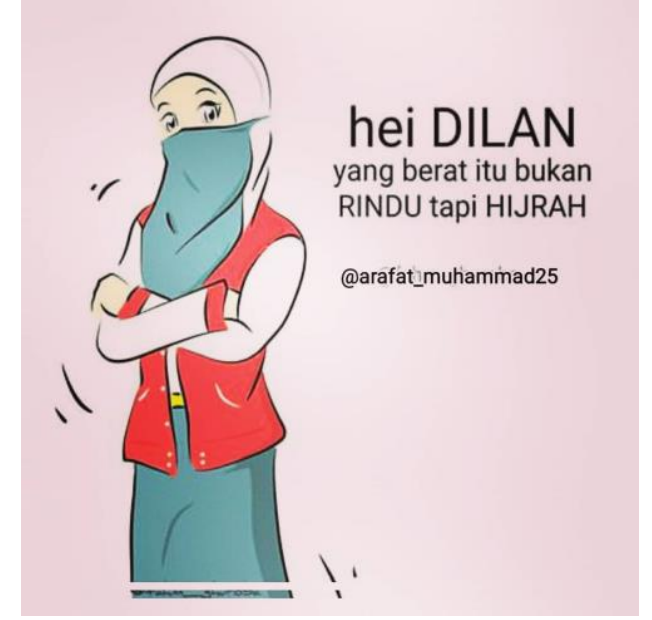

Fig. 7 Islamic Meme about "hijrah", Retrieved from https://deskgram.net/p/1708670301874927406 4921387495

The Islamic Meme above shows an illustration of a Muslim woman who uses a hijab and a face covering or niqab, with her posture folding her hands. The text on the Meme reads "Hey Dilan, the heavy one is not RINDU but HIJRAH".

Islamic Memes can be regarded as a form of cultural activity, because of its ability to convey messages that can build people's perceptions. Therefore, qualitative analysis attempts to analyze Memes as research objects by combining Semiotic theory with Islamic teachings as an ideological basis for sign meaning. The analytical method applied in this study uses the level of signification formulated by Roland Barthes in Fiske, namely the reading of signs in denotation, a relation between signifier and signified whose meaning is direct, to describe "what" is illustrated. And the reading of signs is connotation, a relation between signifier and signified whose meaning is indirect, to describe "how" to illustrate it. The way to understand connotative meaning is also related to the cultural values adopted by the community (Fiske).

\section{Discussion}

In the context of social media, the creation of Islamic Meme in this study was constructed to suit the interests of the millennial generation as heterogeneous and Muslim users of social media.

\section{Read the Signs of Faith in God Through Islamic Memes}

Semiotically, visual signs in an Islamic Memes can be interpreted according to the presentation of illustrations and text, namely the meaning in the level of denotation and connotation. The discussion is based on the idea of the need for millennial generations, especially teenagers who interact with information technology devices every day. The absence of visual product boundaries through information technology has an impact on 
the potential for visual irrationality and the fading of morality boundaries, which can influence users. According to Lyotard (1979) in Edgar \& Sedgwick (145), human minds are ultimately subject to computer hegemony and the subject of thinking is replaced by the tendencies of modern technology, so that knowledge is transformed into a kind of exchange value and a game of power from outside.

This potential is feared to erode human faith, which is invaded every day by various visual sensations, ranging from films, music, games, including outside cultural values that are not in accordance with Islamic teachings. As a result, social media users, especially teenagers tend to fall prey to immorality, prioritize the interests of the world, and forget the goals of achieving happiness in the hereafter.

The invitation to strengthen and increase faith in God Almighty must be continually called upon, especially through social media, as the presence of Islamic Memes as media of da'wah, as a means to counter the effects of information technology that gives birth to disgrace and disgraceful deeds.

Islamic memes as media of da'wah aimed at the interests of the millennial generation needs to be designed in accordance with the needs of users of social media, namely a design that is able to communicate with interesting visualization, provide information with easy-to-digest, short, not patronizing visual language, but can arouse thoughts and feelings. In the creation of Islamic Meme as a messenger of da'wah, these visual considerations must still be related to the provisions in da'wah, including not being propaganda, not justifying any means, intended to be sincere to Allah, and free from the interests of subjectivity, and it is strictly forbidden to contain elements of manipulation.

The following discussion of the four Islamic Meme samples mentioned above focuses on reading visual signs that carry a message of invitation to strengthen and increase faith in God. The analysis of the visual signs includes elements of the illustration in the form of visual characters displayed and sign text elements.

In visual character elements, the meaning of visual signs can be read through facial expressions, body appearance, and body style, including choices of color and shape of lines. The principle of creating a visual character in denotation must reflect the character according to the needs of the user or the target of the da'wah. Whereas in writing text elements, meaning includes the essence of the message to be conveyed through the use of sentences. The whole element of the sign in the discussion is also related to the sociocultural values and Islamic teachings, according to the hadith and the Al-Qur'an.

In the first Islamic meme that carries a message about the meaning of "pious" or "saleh", visual signs in denotation meanings are illustrated by the visual character of a young man dressed in a robe, with a turban head covering. next to it, the body posture is visualized strapping, with the body style shown showing his hands forward, the color element uses harmonious colors, in the form of a combination of green and blue with bright color values, the choice of lines that form the visual character using curved lines.

In connotation, the visual signs of the first Islamic Meme can be interpreted as follows: Illustration displays the style of today's young man who is handsome but still trying to be pious. This is shown through his Muslim clothing in the form of a robe, 
complete with turban covering his hair. Facial expressions that look smiling with one blinking eye are forms of satire and ridicule to young people who tend to prefer to remember the names of music groups or singers whose members are beautiful women. These brightly colored memes invite young people to increase their faith by maintaining their abilities, including remembering the names of the Prophet and the Apostle more than the names of the artist singers.

The word "pious" or "saleh" in Arabic means good, correct (proper, appropriate, appropriate, appropriate), correct, neat (not chaotic, according to the rules), honest, upright, obedient and obedient to the rules, useful, and practical (can apply). People are called pious if godly qualities are present in themselves, namely the nature of kindness, appropriateness, order, neatness, honesty, straightness, obedience, ease, compatibility and conformity (

In the second Islamic Meme that carries a message about the meaning of "wife's role", visual signs in denotation meanings are illustrated in the form of visual characters of hijab woman, who are depicted standing between various household appliances, ranging from washing machines, stoves, iron tools, and also the visual of the school bus. Above the head of the veiled woman, there are symbols of "love". Facial expressions are depicted smiling, and her body style shows that she is interacting with all the equipment that surrounds her. The choice of colors used is a green monochromatic color composition with a color value that tends to be bright, and a choice of dominant curved lines.

In connotation, the visual signs of the second Islamic Meme can be interpreted as follows: Illustration of Muslim woman who is seen busy working on various household chores is a common perception in the community who assume that the role of a wife is indeed the case. Women in the perception of patriarchal culture in Indonesian society also tend to accept this view as a nature that must be lived. Women are required to perform three roles at once, as wives, mothers, and also as Muslim women, so the illustrations are depicted with happy facial expressions, filled with love, sincerity, in order to obtain the blessing of Allah and the blessings of the husband. All household work, from ironing, washing, cooking, delivering school children, is interpreted not as a burden, but has become her responsibility. However, the visual written text of this Islamic meme invites readers to realize the real role of wives in the context of Islamic teachings and faith in Allah, that wives are gifts from Allah that should be guarded and cared for by their husbands, and not vice versa.

Indeed Islam has explained the noble position for women and expressed equality between men and women in many verses in the Qur'an, including QS Al-Hadiid verses 12 and 18, QS At-Taubah verses 71-72, QS An Nisaa verse 124, QS An Nahl verse 97, QS Al Mukmin verse 40, and QS Al Fath verse 5. The Prophet also said, "Whoever pleases or spoils a daughter is like crying out of fear of Allah. And whoever cries out of fear of Allah, Allah forbids his body to go to hell (HR Abu Ya'la, Ahmad) ( $\underline{\text { Amal). }}$.

In the third Islamic Meme that carries a message about the meaning of "love to Allah", visual signs in denotation meanings are illustrated in the form of visual characters of modern dressed men, using t-shirts and trousers, but equipped with a scarf 
around the neck, and typical Muslim head covering. The expression on his face did not look smiling, and his eyes seemed to glance sideways. His body style was seen carrying flowers hidden behind his back. The choice of colors used is the basic white color, and the choice of lines is also dominated by curved lines.

In connotation, the visual signs of the third Islamic Meme can be interpreted as follows: The visualization of the youth presented is the style of today's youth who are often the idols of teenagers. Teenagers are synonymous with anxiety in finding their true identity, especially in puberty. The invasion of information from social media often tempts young people to fall into immoral acts. Youth's anxiety is depicted through a series of flowers hidden behind his back, as a form of fear of his sin, and the temptation of lust against the opposite sex. This Islamic meme aims to build awareness, that love for God is more important than the love of others. Even if we have committed many acts of sin or immorality, in fact Allah's love for his creatures is very broad, and the door to forgiveness is always open to people who repent. The invitation to re-strengthen love and faith in God is reaffirmed through written texts, as an expression of the heart of the young man who feels anxious with his many sins.

An-Nawas bin Sam'an r.a. said that the Messenger of Allah had said, "Virtue is good character. And sin (evil) is something that causes anxiety in you, where you feel unhappy when the action is known to others" (Liem 41).

In the fourth Islamic Meme which carries a message about the meaning of "hijrah", visual signs in denotation meanings are illustrated in the form of visual characters of hijab woman in a modern style, with a blouse and skirt look, using a face covering tied to her head. This Muslim woman is depicted as standing with a slender posture, showing her curves. The facial expression is not visible, but her eyeballs are depicted wide-eyed. The style of her body visualized stands up folding her arms. The choice of colors uses harmonious color combinations, with the dominance of pink, while the choice of lines uses curved lines.

In connotation, the visual signs of the fourth Islamic Meme can be interpreted as follows: the visualization of today's woman is synonymous with fashion and modern hijab models. The style of the veil as a hair cover and head in the culture of society in Indonesia is now interpreted differently in its use, because of the influence of fashion developments. This illustration of a Muslim woman tries to represent the style of today's woman who still look fashionable. But in her efforts to remain faithful to Allah, she keep trying to cover her face to avoid the views of men, or prevent the occurrence of lust for men who were tempted by her face. Facial expressions with wide-eyed illustrations affirm that "hijrah" behavior is not something that is easy and needs an inner struggle, especially if the human heart has fallen in love with the opposite sex, and not to God. Visual signs in the text emphasize this message by linking the narration in the film Dilan which is popular among millennials.

In Islamic teachings, the word "hijrah" can be interpreted differently. But in this Islamic Meme context, the word "hijrah" can be interpreted as an attempt to keep away from something. Referring to several opinions of Ibnul Arabi, the meaning of hijrah 
includes leaving things that are forbidden and looking for something that Allah likes, also interpreted as a journey on earth to seek lessons, wisdom, and advice (Jazuli 19).

Thus the reading of visual signs in Semiotics as a visual language of Islamic Meme that carries the message of da'wah. The dominance of the use of bright colors and curved lines aims to bring visualization that seems soft and flexible. Islamic meme, in its appearance also tends to present the human visual character with all its entities. This can refer to the view of humans as social-cultural beings who each have personalities and interests in their society. In addition, humans are also destined to carry out their functions in the world, namely fulfilling their duties and obligations as creatures of God, social beings, and cultural beings, all of which must be accounted for later in the hereafter.

The spread of Islamic Meme on social media must be addressed as a creativity that has its own place in an effort to spread religious teachings that are in line with the times. Because in practice, Islamic Meme has the power of visual language to build further discussion of the interpretation of meanings conveyed, even though it is in the form of illustrations and short text.

\section{Find Interaction of Culture and Religion Through Islamic Memes}

In the Indonesian Language Dictionary, culture is defined as the result of human activities and reason, through religion or belief, art, and customs. The word culture itself can be interpreted as the result of thought and reason. Whereas Barker ( $\underline{66})$ defines culture as a constellation of a number of transient conformities, or nodes in the social domain as a result of relations and interconnections stretching from local to global scales.

Islamic Memes are the result of human creativity activities, because it contains the interaction of culture and religious teachings. In its development, culture will continue to produce changes according to human needs, according to Iqbal Khan, both individuals and communities will try to complement each other to achieve progress in civilization (Khan 97).

The content of da'wah delivered through Islamic Meme is part of the achievements that humans produce as servants of Allah based on their ability to express and develop themselves. It was said again by Khan (77), in the context of human activities, movements physically, mentally, or spiritually in humans, basically always in the corridor of conformity or contrary to the prevailing religious teachings, but never without religious references. This is because religion can provide a complete solution to all complex problems related to humans.

The spread of Islamic Memes on social media can be said to have an indirect impact on influencing teenagers as a young generation who are now increasingly entangled in the pleasure of producing and consuming cultural products democratically. In the cultural context of Islam, Noor said that, "what we see today is a more complex and nuanced phenomenon of devout and pious Indonesian Muslims who are attempting to work with and engage with globalisation, modernity, and Western culture".

Therefore, the presence of Islamic Memes as a media of da'wah is part of the development of culture in human civilization which still cannot be separated from the 
provisions of da'wah. Humans are also required to hold on to culture so that they are not trapped in the models of creation that are limited to fulfilling certain desires but lose the spirit of the message of da'wah to be conveyed. Even though today's society is in unlimited information disclosure, it still needs some kind of interaction between cultural values and religious values, in order to continue to present "identity" of humanity and divine values.

Islamic Memes cannot be placed as mass production which is in a uniform and instantaneous arrangement of cultural spaces. Islamic Memes that follow the provisions of da'wah are those created with sincerity, honesty, and not based on hidden interests. Visual language in Islamic Memes is designed not only to display imitative images and texts, or to follow contemporary tastes and desires, but it must be intended to be able to build perceptions, arouse emotions, and open minds about truths and virtues in Islam.

\section{Conclusion}

The discussion of the visual language of Islamic Memes is an idea of Islamic Meme visualization, which through the signification system is proven to be able to identify the Islamic Memes image as a media of da'wah in accordance with the socio-cultural values and Islamic teachings in general. Semiotic discussion in Islamic Memes as messengers of da'wah also opens opportunities for broader interpretation of meaning in relation to ideological codes according to community conventions.

This study successfully concluded that Islamic Memes has the potential to become a media da'wah that is able to build an understanding of the teachings of truth through visual language of images and texts. Both design elements influence each other to shape the perception of social media users who read the Islamic Memes. The visual language of images, in this case in the form of illustrations, is designed to represent the needs of the millennial generation, especially teenagers who have daily life and closeness to cyberspace. Islamic Memes, which are intended for millennial generations, must be designed to meet their needs to provide solutions to all problems involving their feelings, daily activities and ideas. The visual language of written text needs to use language that is familiar, easy to digest, and not patronizing, because this can be easily accepted by teenagers.

Islamic Memes that are disseminated through social media, in principle, must still prioritize the provisions of da'wah, including being created with the intention to increase faith in Allah, be honest, sincere, and not based on hidden interests. In addition, religious teachings cannot be packaged in a humorous style, but rather strive to build interactions between culture and religion through the strength of visual elements that attract attention and adapt to the needs of the millennial generation. Islamic memes as media of da'wah can raise common themes that are close to the discovery of human identity as social beings in their daily lives, such as the application of pillars of faith and the rule of Islam. 
In the context of Visual Communication Design, the creators of Islamic Memes need to pay attention to the creation of visual characters and visual styles that become visual strength as the main attraction of Islamic Meme. This is due to the illustration of visual characters, both young men and women are often presented to attract the attention of social media users. In addition, the visualization of facial expressions, body postures, and costumes displayed on the visual character model is designed to represent the tastes of Muslim youth as millennials. The selection of the sex of the visual character is not very significant, because basically Islamic Meme is more focused on the message of da'wah.

The creation of Islamic meme as a media da'wah needs to be carried out continuously because of the rapid development of information technology that brings various impacts, both positive and negative for its users. This study can be a scientific reference to maximize the potential of the visual element in communicative and informative Islamic Meme creation. Studies show that the visual language of Islamic Memes can be designed to be visual signs that are meaningful according to the culture of society.

\section{Acknowledgement}

Appreciation and gratitude to the Institute for Research and Community Service (LPPM) of Universitas Indraprasta PGRI Jakarta which has supported this research activity.

\section{BIBLIOGRAPHY}

Al-Quran dan Terjemahan

Adhiwiayanti, Anindita. Meme Dibaca Mim. Bukune, 2015.

Alamsyah, Ryan. "Analisis Etnografi Virtual Meme Islami Di Instagram Memecomic. Islam." Fakultas Ilmu Dakwah Dan Ilmu Komunikasi UIN Syarif Hidayatullah Jakarta, 2018.

Amal, Andi Sri Suriati. Role Juggling: Perempuan Sebagai Muslimah, Ibu, Dan Istri. Gramedia Pustaka Utama, 2013.

Barker, Chris. Kamus Kajian Budaya. PT Kanisius, 2014.

Brodie, Richard. Virus of the Mind. Hay House, Inc, 2009.

Danesi, Marcel. "Pengantar Memahami Semiotika Media, Terjemahan: A." Gunawan Admiranto, Yogyakarta: Jalasutra, 2010.

Edgar, Andrew and Peter Sedgwick. Cultural Theory: The Key Concepts. Routledge, 2007.

77 Cultural Syndrome, Vol.1, No.1, 2019, pp. 61-78

https://doi.org/10.30998/cs.v1i1.16 
Farihah, Irzum. "Media Dakwah Pop." AT-TABSYIR; Jurnal Komunikasi Penyiaran Islam, vol. 1, no. 2, 2013, pp. 25-45.

Fiske, John. Cultural and Communication Studies-Sebuah Pengantar Paling Komprehensif. 2010.

Ismail, Ilyas and Prio Hotman. Filsafat Dakwah Rekayasa Membangun Agama Dan Peradaban Islam. Kencana, 2013.

Jazuli, Ahzami Samiun. Hijrah Dalam Pandangan Al-Qur'an. Gema Insani Press, 2006.

Khan, Asif Iqbal. Agama, Filsafat, Seni Dalam Pemikiran Iqbal. translated by Farida Arini, Fajar Pustaka Baru, 2002.

Liem, Koko. Membuka Pintu Tobat, Jauhkan Maksiat. Raih Asa Sukses (Penebar Swadaya Group), 2011.

Luth, Thohir. M. Natsir, Dakwah Dan Pemikirannya. Gema Insani Press, 1999.

McKim, Robert H. Thinking Visually: A Strategy Manual for Problem Solving. Lifetime learning publications Belmont, CA, 1980.

Mirzoeff, Nicholas. An Introduction to Visual Culture. Routledge, 2009.

Mustajab, M. Latifu. Hanan. "Analisis Resepsi Remaja Islam Surabaya Tentang Meme Islam Di Media Sosial." Pascasarjana Disertasi, Universitas Islam Negeri Sunan Ampel Surabaya, 2018.

Noor, Farish A. "Popular Religiosity in Indonesia Today: The Next Step after 'Islam Kultural'?" Al-Jami'ah: Journal of Islamic Studies, vol. 53, no. 2, 2015, pp. 283-302, doi:https://doi.org/10.14421/ajis.2015.532.283-302.

Piliang, Yasraf Amir. Bayang-Bayang Tuhan: Agama Dan Imajinasi. Mizan Publika, 2011.

Sarup, Madam. Panduan Pengantar Untuk Memahami Postrukturalisme Dan Posmodernisme. translated by Medhy Aginta Hidayat, Jalasutra, 2011. 